\title{
The Role of Professional Associations in Supporting Election Administration
}

\section{Tim Mattice}

\begin{abstract}
The creation of professional education programs for election administrators requires not only a thorough understanding of the varying structures and administrative responsibilities for election administration across the United States but also an understanding of approaches for adult education. As many election officials come to the field with limited, if any, formal education in election administration, providing opportunities not only for education but also for networking is essential to creating a more professional cohort of administrators. This case focuses on the creation of the first professional association and education program for election administrators in the United States.
\end{abstract}

Keywords Professionalism • Election Center • Help America Voter - Auburn University

I have had the good fortune to be involved in adult education for 34 years, 23 of those years working in some capacity in election systems both at the state and at the local level.

T. Mattice $(\bowtie)$

Election Center, Katy, TX, USA

e-mail: tmattice@electioncenter.org

(C) The Author(s) 2019

M. Brown et al. (eds.), The Future of Election Administration, Elections, Voting, Technology, https://doi.org/10.1007/978-3-030-18541-1_19 
In choosing a case study topic to contribute, I decided to look at the past 20-plus years and explore the timeline, from my perspective, of adult education and the role it has played in the professionalization of election administrators.

In the 1980s it was not unusual that election administrators remained in their jobs for 20- or 30-plus years. Working in elections became their career path despite their admission that the elections field was not necessarily their first profession of choice. However, once found in this role, elections got in their blood and despite challenges in pay, lack of public affirmation, and availability of resources, they endured. Election officials at that time were focused on their own jurisdictions maintaining voting systems, recruiting poll workers, securing poll sites, and acquiring the resources needed to prepare for the next election. Federal and state legislation on occasion required election officials to institute changes in their operations but, for the most part, the administration of elections was business per usual according to state rules and regulations and change was minimal from election to election.

Some election officials, like county clerks, not only wore voter registration and election administration hats but were responsible for other duties which could include filing vital records, or important documents related to a specific county's population, including birth, death, and marriage certificates. The county clerk, depending on the state, may also have to file and process residents' passport applications and property deeds, administering department of motor vehicle programs, issue county IDs, give and file licenses for local doctors and business owners. Some county clerks also confirm and license notary publics and sometimes officiate wedding ceremonies.

Public perception dictated to a certain degree that election officials worked just two days out of the year, the primary and the general election. The election official's job was to register people to vote, maintain the voter registration files, and locate sites in their communities for voters to come on Election Day to cast their votes. Election officials were viewed as public servants but the election official wasn't viewed through the same professional lens as other health and human service-related professions such as a nurse, physician, pharmacist, social worker, teacher, lawyer, or engineer. Public perception prevailed that election officials only worked two days per year-so how challenging could their jobs really be?

In the late 1980s election officials began to communicate issues between states, including election systems, organizational configurations, and 
operational methodology. The Election Center, also known as the National Association of Election Officials, at the time was instrumental in jumpstarting the National Association of State Election Officials (NASED). At the time, a handful of state election directors including Tom Wilkey (New York), Tom Harris (Texas), and Chris Thomas (Michigan) among others worked to create an association where state election directors would have a forum to discuss and share information related to important issues like voting technology certification and a formal network to communicate election issues between states and provide a vehicle to impart critical operational impacts to Congress when new legislation was being introduced. Ultimately, during the 1980s, NASED developed and maintained the first voting system certification program in the United States. NASED's membership included the 50 states, the District of Columbia, and 5 of the US territories, and there was no central office to manage the association's operations. At the organization's inception, the Council of State Governments became the administrative arm for the association until 2005, when the Election Center was asked by NASED leadership to take over the fiscal and administrative responsibilities for the organization. At this time, the Executive Director of the Election Center also took on the added role of NASED's first Executive Director. The Election Center continued in the role of NASED Secretariat for over a decade; it was responsible for coordinating biannual NASED conferences, maintaining the membership database and collection of dues, and creating and maintaining NASED's first website. As Secretariat, the Election Center also created NASED's first electronic registration system for biannual conferences and payment of dues including management of all of the finances for the organization. The Election Center also conducted surveys for NASED. The surveys were requested by state directors, developed via an online tool, and sent out to state directors and their staffs. Results were then compiled and disseminated to the association membership. Creating agendas for NASED events, recruiting federal, state, election services partners and other professionals with knowledge in election and voter registration issues as speakers for NASED conferences, and providing the opportunity for state directors and their staffs to fulfill mandatory Continuing Legal Education obligations at certain conferences were some of the responsibilities that the Election Center assumed in managing the NASED organization through the Secretariat.

Prior to 1989, there were no professional associations exclusively for election administrators. Many attended the National Association of 
Secretaries of State (NASS) meetings to learn about developments in election administration. The National Association of Secretaries of States has been in existence since 1904, the nation's oldest, nonpartisan professional organization for public officials. NASS served as a medium for the exchange of information between states and fostered cooperation in the development of public policy. The association had key initiatives in the areas of elections and voting, state business services, and state heritage/ archives but election administration was just a piece of their purview.

In the late 1980s and early 1990s, a small group of election officials began a conversation about what could and would professionalize the election officials' job, and would recognize the proficiency level needed for election officials to carry out the responsibilities which were more than providing the means to register eligible voters, maintaining voter rolls, securing, storing, testing and setting up and maintaining voting equipment, recruiting and training poll workers, counting the vote and officiating the results. Other professions had licensing requirements, specific academic requirements that defined who they were as professionals, what they did, and how they did it. These professions included codes of conduct and standards and principles that held the professional accountable in order to maintain his/her status in their profession.

So the conversation ensued and the question was asked, why not develop academic requirements, standards and principles, and codes of conduct for election officials? The academic connection was key in creating a program that substantiated the role of the election official to county, state, and federal leaders as a profession necessitating a complex skill set for those who truly were the gatekeepers of democracy. Election officials needed to know the history of voting to put their current profession into a historical perspective. They needed to know the fundamentals of ethics, how to communicate effectively with the public, the media, candidates, and with state and federal officials. They needed to know how systems worked and how to implement new programs. They needed to have an understanding of federal laws and planning and operating budgets, and so on. All these ingredients were included in courses that would be recognized within higher education, in a range of topics that melded election administration with principles of public administration and concepts to create a national certification program for election administrators.

The Election Center or National Association of Election Officials has been offering conferences and workshops for election officials since the mid-1980s. Partnering with Auburn University, an accredited academic 
institution, they began to collaborate and develop a series of classes that would set the stage for the first established certification program available for election administrators in the country. By the early 1990s, initial courses were developed and offered to election officials at Election Center venues across the country, with the goal of completing a specified level of content included in a set number of courses. Completion of the series of classes would culminate in a professional certification through the Election Center and continuing education units at Auburn University that could later be applied to further an election official's post-secondary education.

The Election Center and Auburn University's professional education program was the first and remains the only opportunity for election officials to achieve a level of professional certification within the elections profession. In 1995, the first group of election officials graduated as Certified Elections Registration Administrators (CERA).

The need for a certification program became even more apparent after the presidential election in 2000 and the adoption of the Help America Vote Act (HAVA). This legislation changed the role of the election administrator and set them on a path that necessitated an advanced degree of professional education to survive in the increasingly complex field of election administration. Seemingly overnight election officials were propelled into the public arena amid new expectations, heightened transparency, intensified accountability, creation of state voter databases and new voting systems. All facets of election administration were shifting to meet the mandates resulting from HAVA. The need for election official professionalization and education was no longer an extracurricular goal but a necessity. New requirements placed on election officials demanded a higher degree of skill that resulted in many veteran election officials retiring and a wave of new, younger, inexperienced election officials entering the field. To respond to these changes, Auburn University's Election Administration Initiative created a Graduate Certificate in Election Administration. The Graduate Certificate in Election Administration is a 15-credit-hour program that can be earned within the Auburn University Master of Public Administration (MPA) Program or as a separate certificate. As approved by Auburn, CERA certification qualifies for 3 graduate credit hours toward the graduate certificate.

As the Election Center programs expanded and evolved to meet the needs of the new era of election administrator, the professional education program was expanded to include election vendors. Those companies that served election offices with voting systems and variety of election services 
and products were now presented with an opportunity to learn the depth and details of the election administrators' job to better serve their needs and also to attain their professional certification as a Certified Registrations Election Vendor.

I have witnessed throughout my 34 years of training adults that the added value in face-to-face instructor-led training is invaluable for many reasons. Electronic training (E-training) has a place and can be an effective way of delivering a message to a lot of people without the cost and time of travel. However, when you are captive in a room with a group of your peers, you are more focused on the learning and distractions are minimized. For 26 years, since the first professional education classes were offered, it's been stated repeatedly by election officials class after class, year after year, that the opportunity to work together with other election officials from around the country and learn how they do things differently in their states is as valuable an aspect of the professional education program as the course content. The degree of focus resulting from a distractionfree environment (a classroom) creates a robust opportunity for students to be physically and mentally present and to be committed to the outcome of the experience. This sense of presence and focus is taken one step further with the work done in small groups. As one example, a public administration concept, process, or model is introduced to the classroom of students, who then break into small groups with an assignment. Working together in the small groups, they then report their findings back to the larger group, ultimately enhancing their skill base and sharing ideas and best practices which often can be applied in their workplaces. These are just a few of the comments made by students as a result of working in the face-to-face classroom environment:

"The opportunity to collaborate and learn from election officials from all around the country is invaluable."

"Sharing stories and experiences with these officials has had a tremendous effect on how I run my local elections office."

"The Professional Education Program has taught me that we are in it together no matter the state or county."

"It's a great resource to brainstorm with other election officials throughout the country that normally your paths would not cross."

Face-to-face instruction also offers instructor adaptability in the delivery of course content when, for example, the ratio of less experienced 
election officials is higher than the more experienced officials in a particular class.

A classroom environment also provides a safety zone for the election officials among peers who understand what their colleagues experience and this camaraderie encourages the election officials to share within the confines of the group and know that what is said in the classroom stays in the classroom. Building personal relationships with face-to-face instruction is paramount in trust and confidence building and has resulted in election officials not only participating in the course content leading to their certification but also volunteering to be members of task forces, special project steering committees, and other committee opportunities offered by the Election Center and Auburn University that involve a variety of jurisdictions from small, medium, and large election operations. This results in election officials coming away with their own personal network of experts to call upon after the training is complete. Many of the election officials who go through the program form bonds and professional friendships that last for many years after they attain their initial certification.

Over the past three decades, election officials in the United States have had to adapt to an escalating cadre of demands and an ever-increasing level of knowledge required to get from point A (providing the vehicle for registering a person to vote) to point B (providing a safe and accessible voting environment) to point $\mathrm{C}$ (canvassing the votes and declaring the winners). Given the intricacies of today's elections and understanding the number of organizations and individuals that election operations impact in some way, success hinges on the election administrator having the knowledge, tools, and resources to implement their duties. Providing a professional education program that adapts and changes to meet the expanding demands of the profession has become an institutional necessity, a vehicle to foster and ensure that success. That success relies in part on professional education continually restructuring and providing opportunities for election administrators to come together, learn public administration concepts and ideologies, and apply those concepts in real time by sharing and learning with and from their peers. As Benjamin Franklin reminds us: Tell me and I forget. Teach me and I remember. Involve me and I learn. 
Open Access This chapter is licensed under the terms of the Creative Commons Attribution 4.0 International License (http://creativecommons.org/licenses/ by $/ 4.0 /$ ), which permits use, sharing, adaptation, distribution and reproduction in any medium or format, as long as you give appropriate credit to the original author(s) and the source, provide a link to the Creative Commons licence and indicate if changes were made.

The images or other third party material in this chapter are included in the chapter's Creative Commons licence, unless indicated otherwise in a credit line to the material. If material is not included in the chapter's Creative Commons licence and your intended use is not permitted by statutory regulation or exceeds the permitted use, you will need to obtain permission directly from the copyright holder. 